\title{
EPSL
}

Earth and Planetary Science Letters 136 (1995) 475-494

\section{Late Miocene magnetostratigraphy, biostratigraphy and cyclostratigraphy in the Mediterranean}

\author{
W. Krijgsman ${ }^{\text {a }}$, F.J. Hilgen ${ }^{\text {b }}$, C.G. Langereis ${ }^{a}$, A. Santarelli ${ }^{c}$, W.J Zachariasse ${ }^{b}$ \\ ${ }^{2}$ Paleomagnetic Laboratory, Fort Hoofddijk, Budapestlaan 17, 3584 CD Utrecht, The Netherlands \\ ${ }^{b}$ Department of Geology, Institute of Earth Sciences, Budapestlaan 4, 3584 CD Utrecht, The Netherlands \\ ' Laboratory of Palaeobotany and Palynology, Heidelberglaan 2, 3582 CS Utrecht, The Netherlands
}

Received 5 May 1995; accepted 26 October 1995

\begin{abstract}
A new chronology for the late Miocene of the Mediterranean is presented by combining magnetostratigraphic, biostratigraphic (planktonic foraminifera and dinoflagellates) and cyclo-stratigraphic data. Long and continuous upper Miocene sections on Gavdos (Metochia section) and Sicily (Gibliscemi section) display cyclic alternations of homogeneous marls and sapropels and can be correlated on the basis of their distinct cyclic patterns. The Metochia section yields a good paleomagnetic signal and the position of 17 polarity reversals can be determined. The resulting polarity sequence allows an unambiguous correlation to the geomagnetic polarity time scale (GPTS). The paleomagnetic signal in the Gibliscemi section is too weak to determine a reliable polarity sequence, except for the lowermost part of the section. Detailed biostratigraphic analysis results in the identification of 13 planktonic foraminiferal and 9 dinoflagellate bioevents, which can all be accurately dated. The Tortonian/Messinian boundary, defined by the First Regular Occurrence (FRO) of the G. conomiozea group, is determined in chron C3Br.1r with an age of $7.12 \mathrm{Ma}$, according to the GPTS (CK95) of Cande and Kent [1].
\end{abstract}

\section{Introduction}

The chronology of the Mediterranean Pliocene and Pleistocenc has improved substantially during the last decade since several integrated magnetostratigraphic and biostratigraphic studies have been published on land sections and deep sea cores in the eastern Mediterranean [2-6]. All these sections reveal characteristic sedimentary cycle patterns, which were shown to be related to the Earth's orbital cycles of precession and eccentricity. These sections were used to construct an astronomically calibrated polarity time scale (APTS) for the Plio- and Pleistocene $[7,8]$. Such an APTS proved to be more accurate and to have a higher resolution than conventional time scales.

The chronology of the Mediterranean late Miocenc, however, is still very poor and restricted to sediments of late Tortonian-early Messinian age. Suitable land-based sections consisting of open marine sediments are rare. On Crete, good paleomagnetic results were obtained from various sections consisting of cyclically bedded marine marls $[9,10]$. These sections, displaying bipartite sedimentary cycles, do not extend further than 7.7 Ma [11]. Paleomagnetic results from late Miocene sequences in Sicily and northern Italy are disappointing. Sections represent too short an interval [9], have unsuitable 
paleomagnetic properties [12], or are completely overprinted by a present-day normal field component [13]. Finally, magnetostratigraphic studies from ODP site 654 in the Tyrrhenian sea gave reasonable results but again here the succession is restricted to sediments younger than $7 \mathrm{Ma}$ [4].

Our present research aims at the development of a reliable and accurate chronostratigraphic framework for the late Miocene and the extension of the PlioPleistocene APTS into the Miocene. We have found long and continuous upper Miocene sections consisting of an alternation of marine marls and sapropels on the island of Gavdos (Greece) and on Sicily (Italy). These sections have been sampled in detail, within the framework of the EU-sponsored MIOMAR project, and appeared to be very suitable as Mediterranean reference sections for the late Miocene.

In this paper, we present a new and detailed integrated magnetostratigraphy, biostratigraphy and cyclostratigraphy for the upper Miocene from these sections on Gavdos and Sicily. Furthermore, we incorporate earlier results from sections on Crete for the interval straddling the Tortonian/Messinian boundary [11]. The direct calibration of the sedimentary cycles to the astronomical records and the resulting numerical ages for the individual polarity reversals and biostratigraphic datum planes is presented in Hilgen et al. [14].

\section{Sections and sampling}

The two main sections used in this study are the Metochia section on Gavdos and the Gibliscemi section on Sicily which both consist of open marine, cyclically bedded marl sequences (Fig. 1). Additional data are supplied by sections from Crete (Faneromeni, Kastelli) which have previously been studied [9-11]. In all sections, sampling was aimed at a minimum of four levels per sedimentary (precession-related) cycle which corresponds to a resolution of approximately $5 \mathrm{kyr}$. At each level we took four cores; two standard-oriented paleomagnetic cores and two additional cores for biostratigraphical, sedimentological and geochemical purposes. At some levels, mainly in the laminated beds, it was impossible to drill an oriented core and we only took a non-oriented handsample for biostratigraphic analysis.
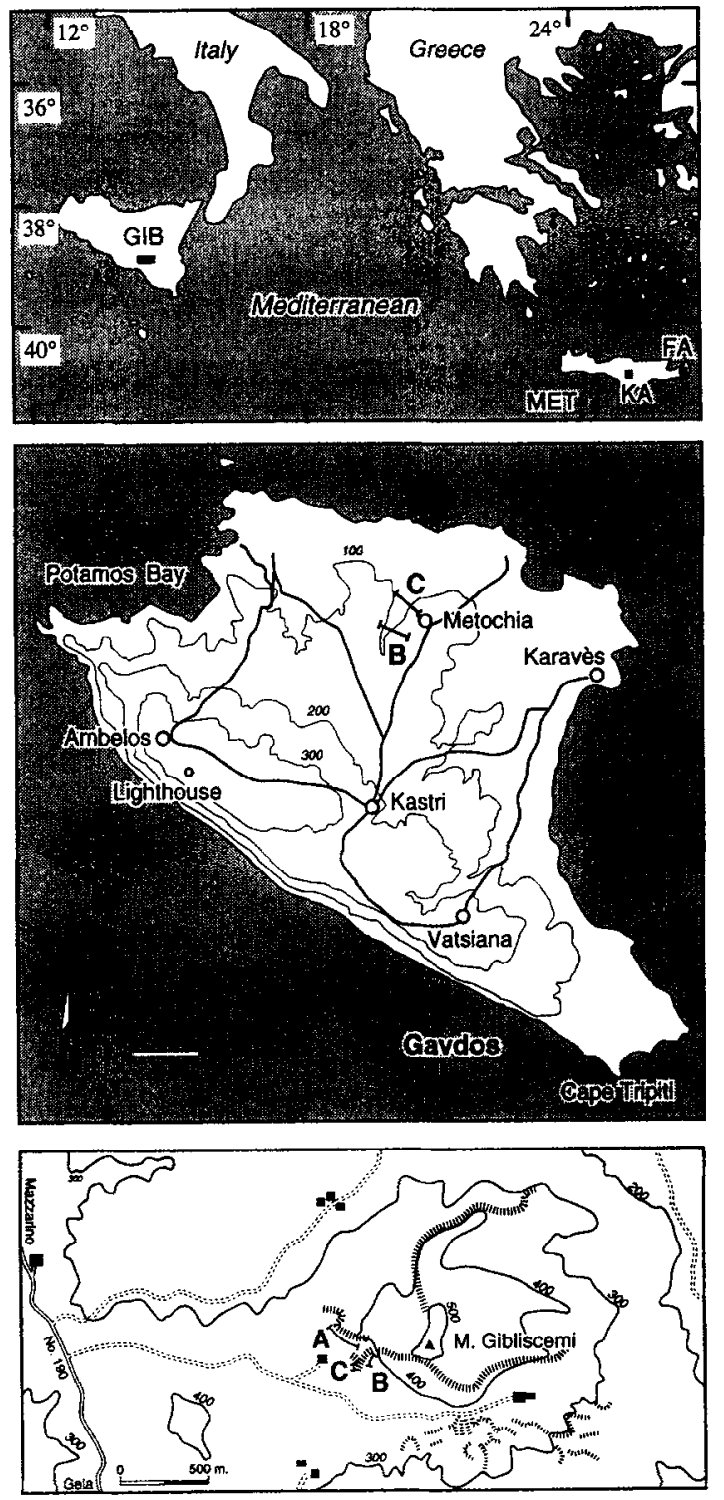

Fig. 1. Location map of the Metochia (MET), Gibliscemi ( $G I B)$, Kastelli (KA) and Faneromeni (FA) sections (top); detailed maps showing the trajectories of the subsections Metochia $\mathrm{B}$ and $\mathrm{C}$ (middle) and Gibliscemi A, B and C (bottom).

\subsection{Gaudos: Metochia section}

The island of Gavdos is located approximately 30 $\mathrm{km}$ south of Crete and represents the southernmost emerged part of the Hellenic arc system. The 
Metochia section is located on the northern part of the island and is composed of two subsections (Metochia $B$ and $C$ ) which are separated by a normal fault (Fig. 1; [15]). These subsections are correlated on the basis of characteristic lithology patterns.

The basal part of Metochia B is formed by a paleosol which is overlain by sediments characteristic of an estuarine environment and shallow-marine sands rich in Heterostegina, echinoderma and molluscs. These so-called Heterostegina sands rapidly pass into deep-marine $(>200 \mathrm{~m})$ sediments consisting of an alternation of hemipelagic marls and brownish laminated beds (sapropels) which are numbered Ml to M96 (Fig. 2). In the lower part of Metochia B (M7-M11) five successive turbiditic sequences occur within or entirely replace the sapropelitic intervals [16]. In the part of the section below the turbidites we succeeded to drill in fresh (blue) coloured sediments after removing the weathered surface. The middle part of the Metochia B section is thoroughly wcathered - many samples are characterised by rusty spots - and even after serious efforts no fresh samples could be drilled.

Metochia C predominantly consists of a rhythmically layered succession of hemipelagic marls and sapropels. In the upper part of the section, the thickness of the sedimentary cycles decreases although several thin turbiditic beds are intercalated. Metochia C is sampled from cycle M36 to M96, resulting in an overlap of 20 cycles with Mctochia B. The sediment is less weathered and brown rusty spots are absent. The sapropel-bearing succession in the Metochia section is overlain in stratigraphic continuity by cyclically bedded diatomites of Messinian age. These diatomites, which contain some 38 cycles, are not included in the present study.

We sampled 560 levels over a stratigraphic interval of approximately $100 \mathrm{~m}$, which corresponds to an average spacing of $20 \mathrm{~cm}$. A second sampling trip was organised to confirm several important polarity reversals and to resample the weathered part of Metochia B for magnetostratigraphic purposes only.

\subsection{Sicily: Gibliscemi section}

The Gibliscemi section is located on the southern slope of Monte Gibliscemi on the southern part of the island of Sicily (Fig. 1). Here, upper Miocene sequences start with a cyclic alternation of homogeneous hemipelagic marls and sapropels, followed by the diatomites of the Tripoli Formation (Messinian) and capped by the Calcare di Base and evaporites (gypsum) of the Gessoso-Solfifera Formation.

The basal part of the Gibliscemi section is tectonically disturbed and overlies the so-called "argillescagliose" which forms the decollement level of thrust nappes. Various shear planes cause important deformations/hiatuses and no continuous section could be sampled along a single trajectory. We succeeded in obtaining a relatively undisturbed and continuous succession - in which the sapropels are numbered (G1-G99, Fig. 3) - by sampling three separate subsections (Gibliscemi A, B and C; Fig. 1) which can be correlated on the basis of their distinct characteristic cyclic patterns. In our composite section, deformation is only bedding-parallel and (predominantly) restricted to sapropels. Only in the top part of the section, a shear plane is found which runs obliquely to the bedding, in the interval preceding the diatomites of the overlying Tripoli Formation.

A total of 620 levels has been sampled in the three subsections, corresponding to an average spacing of $20 \mathrm{~cm}$. A second sampling trip was made to focus on the lowest part of the section. We resampled the interval comprising cycles $\mathrm{Gl}-\mathrm{G} 25$ in the Gibliscemi $A$ and $C$ sections to obtain a more reliable magnetostratigraphy.

\section{Cyclostratigraphy}

All sections consist of open-marine sediments that show cyclic alternations of either whitish-coloured carbonate-rich and grey-coloured carbonate-poor marls (Faneromeni section; lower part), or of homogeneous marls and brownish-coloured laminated beds termed sapropels (see [11]). Fspecially these sapropels reveal characteristic patterns - with both smallscale and large-scale clusters in addition to the individual sapropels - which allows the sections to be correlated (cyclostratigraphically) in detail. The sedimentary cycle patterns of the studied sections and their correlation to the astronomical target curves are discussed in detail by Hilgen et al. [14]. 


\section{METOCHIA}

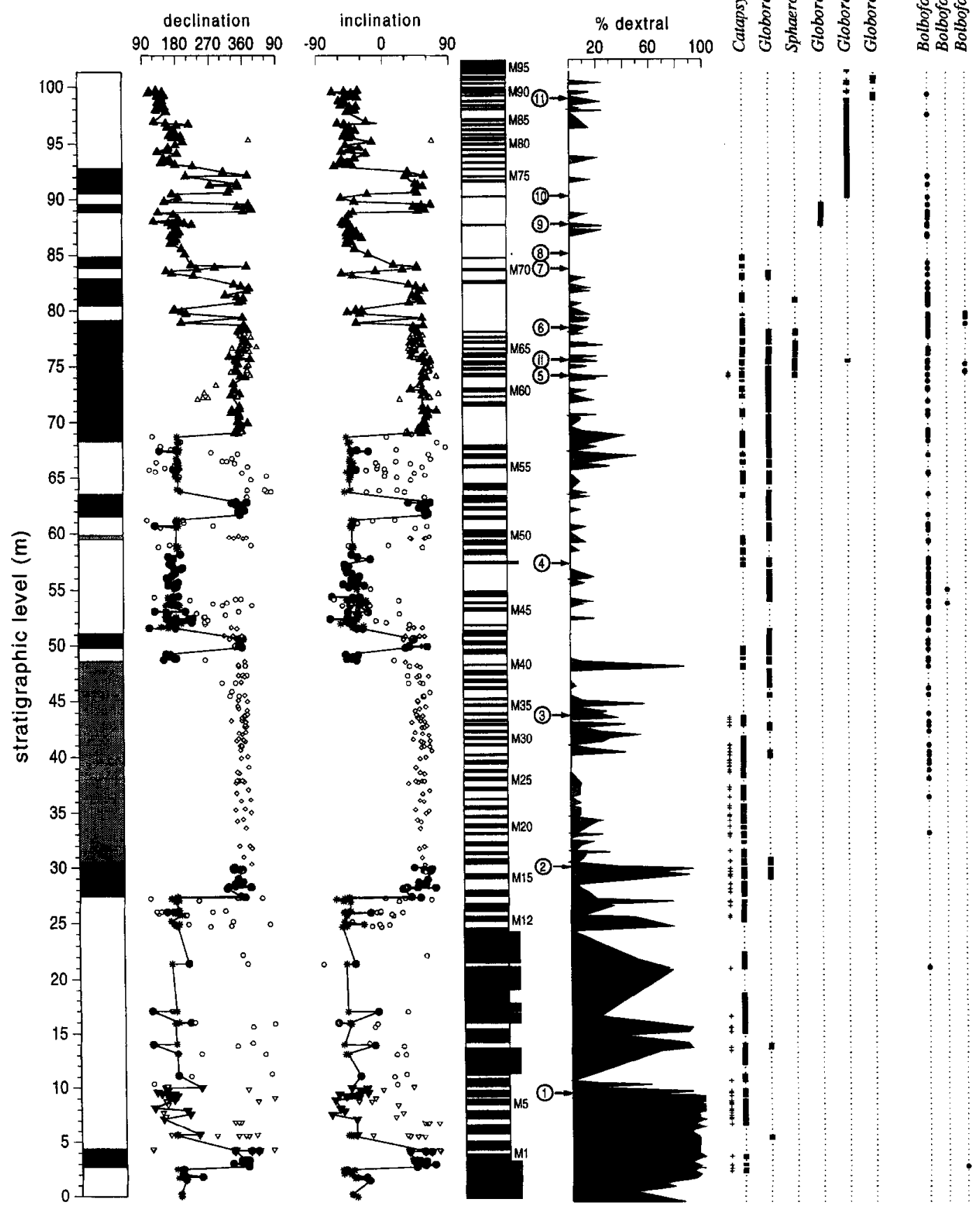




\section{Magnetostratigraphy}

Thermal demagnetisations were performed in a magnetically shielded, laboratory built furnace. The natural remanent magnetisation (NRM) was measured on a $2 \mathrm{G}$ Enterprises cryogenic magnetometer. At least one specimen per sampling level was thermally demagnetised using temperature increments of $30-50^{\circ} \mathrm{C}$. Furthermore, we performed some rock magnetic tests to identify the dominant carriers of the magnetism, including acquisition of an isothermal remanent magnetisation (IRM) and subsequent demagnetisation of this IRM. The IRM was induced in a pulse magnetiser and measured on a digitised spinner magnetometer based on a Jelinek JR3 driver unit. After each step we measured the low field susceptibility which was measured on a Kappabridge KLY-2.

\subsection{Gavdos: Metochia section}

Thermal demagnetisation of the samples from the Metochia section revealed different types of demagnetisation behaviour, which appeared to be rather constant throughout specific intervals. Viscous behaviour, when heated above temperatures of $400^{\circ} \mathrm{c}$, is shown by the marly interval below the turbidites (M1-M6). Good-quality demagnetisation (linear decay) is observed in the Heterostegina sands, the turbidites and four following cycles (M7-M15), the upper part of Metochia B (M43-M56) and the lower part of Metochia C (M36-M56, with exception of M49). Low-intensity clusters at temperatures between 240 and $600^{\circ} \mathrm{c}$ are observed in the middle part of Metochia B (M16-M42) and the upper part of Metochia C (M57-M93) but show different behaviour in these two subsections. We performed some rockmagnetic tests on a number of samples from each interval to characterise the magnetic properties and to distinguish primary from secondary components. On the basis of these experiments, we divided the samples in four groups (Fig. 4). For each group, all selected samples show the same typical behaviour. Therefore, we assume that all samples showing the same demagnetisation behaviour can be attributed to the same group.

\subsubsection{Group A}

Group A is characterised by the dominance of a low-coercivity mineral with maximum blocking temperatures below $600^{\circ} \mathrm{C}$ (Fig. 4a) indicating the presence of magnetite. Heating of the samples to temperatures above $390^{\circ} \mathrm{C}$ results in a sudden increase of susceptibility which continues up to temperatures of $500^{\circ} \mathrm{C}$. This behaviour was observed earlier in suboxic to anoxic sediments and may be the result of oxidation of an iron sulphide like pyrite [17]. The decrease in susceptibility between 500 and $600^{\circ} \mathrm{C}$ can be ascribed to oxidation of magnetite to hematite.

Samples attributed to group $A$ are found in the lowermost 6 cycles (M1-M6) of Metochia B, between the Heterostegina sands and the turbidites. NRM intensities range from 0.04 to $2 \mathrm{~mA} / \mathrm{m}$, initial susceptibilities from 90 to $180 \times 10^{-6} \mathrm{SI}$. The characteristic remanent magnetisation (ChRM) is usually largely removed at temperatures ranging from 300 to $390^{\circ} \mathrm{C}$. Demagnetisation diagrams for this interval show both normal and reversed polarities (Fig. 5c,d)

\footnotetext{
Fig. 2. Polarity zones, lithology, cycle numbers and ranges of planktonic foraminifera, Bolboforma and dinoflagellates of the Metochia section. In the polarity column black (white) denotes normal (reversed) polarity interval and shaded interval denotes zone of undefined (only secondary components) polarity. Closed (open) symbols denote reliable (unreliable) directions. $\nabla=$ group A samples; - group B samples; $\forall=$ group $C$ samples; $\Delta=$ group D samples; $*=$ directions obtained by applying the great-circle method [18]. Lithology column shows cyclic alternations of homogeneous marls (white) and sapropels (black); shaded interval represents turbiditic intercalations [16]. Right part of the figure shows biostratigraphic data given in terms of absence/presence. Numbered bioevents (encircled) refer to (1) highest regular occurrence (hro) of dextral $N$. acostaensis, (2) lowest common occurrence (lco) of $G$. menardii 4, (3) Last Common Occurence ( $\mathrm{LCO}$ ) of large-sized $C$. parvulus, (4) frequency shift (fs) in C. parvulus, (5) lowest regular occurrence (lro) of $S$. seminulina, (6) hro of $S$. seminulina, (7) LCO of G. menardii 4, (8) LO of C. parvulus, (9) First Occurrence of G. menardii 5 (FO), (10) First Regular Occurrence (FRO) of the G. conomiozea group, and (11) FO of G. nicolae, (I) FO of the $G$. conomiozea group. Arrows indicate positions of bioevents. $+=$ large-sized types of $C$. parvulus.
} 


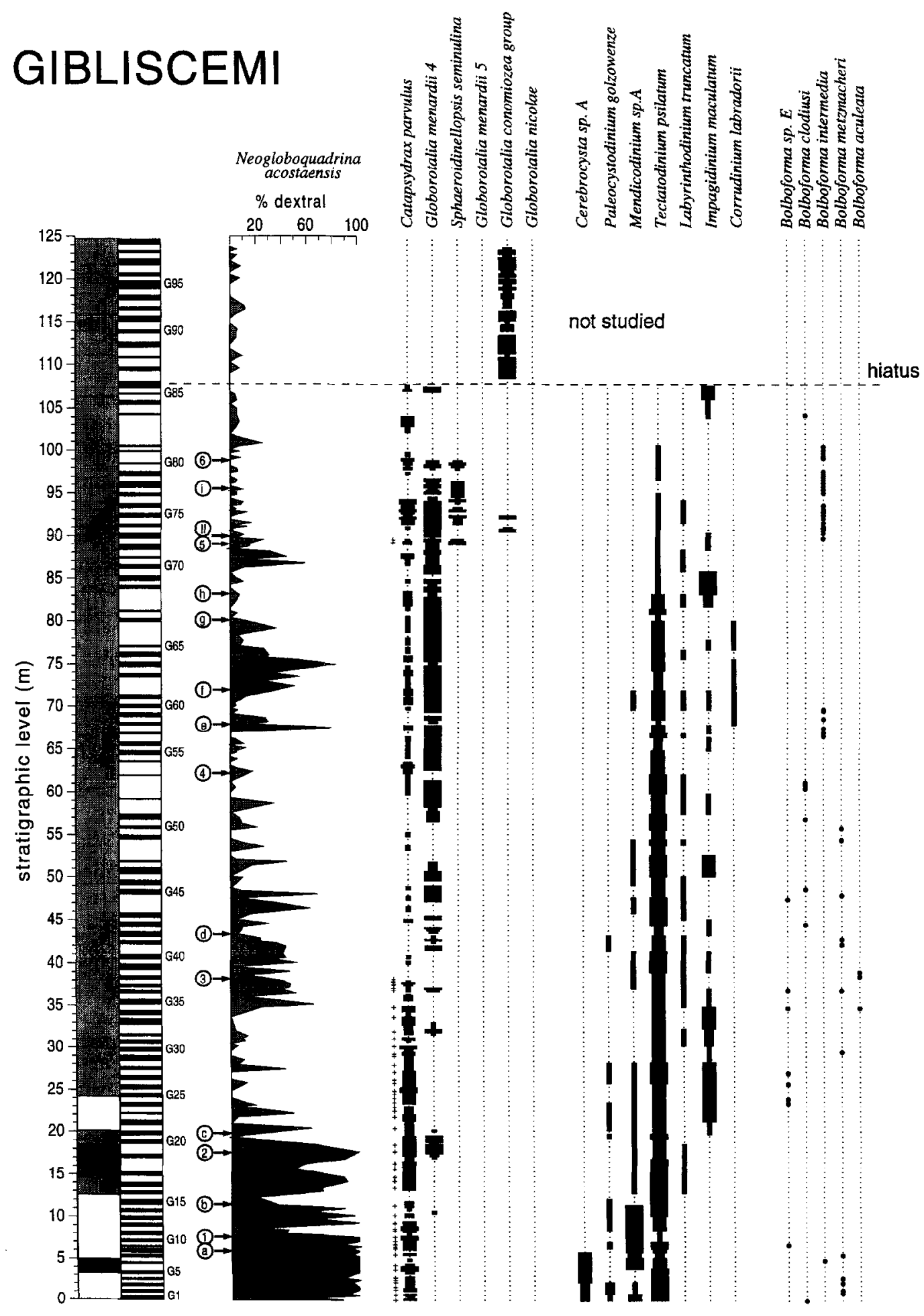


suggesting a primary origin for this component. Further demagnetisation at higher temperatures results in a mainly randomly directed viscous component.

\subsubsection{Group B}

IRM acquisition of group B samples indicate the presence of both a low-coercivity (magnetite) and a high-coercivity mineral (Fig. 4b). IRM demagnetisation shows that at least one component persisted at temperatures higher than $600^{\circ} \mathrm{C}$. Approximately at $680^{\circ} \mathrm{C}$ the IRM is totally removed which indicates that the high-coercivity mineral is hematite. Most samples show no significant change in susceptibility during the heating experiments. Samples which are attributed to group B are observed in the Heterostegina sands, cycles M7-15 and M43-56 in Metochia B and in cycles M36-M56 (except M49) in Metochia C.

NRM intensities range from 1 to $7 \mathrm{~mA} / \mathrm{m}$, susceptibilities from 100 to $200 \times 10^{-6}$ SI. Thermal demagnetisation diagrams show that in most samples a large secondary present-day field component is removed at $240^{\circ} \mathrm{C}$ (Fig. $5 \mathrm{a}, \mathrm{j}, \mathrm{k}$ ). Demagnetisation at higher temperatures reveals both normal and reversed components and again suggests a primary origin of the ChRM. Demagnetisation diagrams are generally of good quality and in most cases the polarity can reliably be determined. Some samples do not show a linear decay to the origin but move successively toward the reversed quadrant of the Zijderveld diagram (Fig. 5e). We assume that the primary component is partly overprinted by a secondary component caused by overlapping blocking temperature spectra. When plotted on an equal-area diagram, remanence vectors progressed along a great circle toward a southerly upward direction indicating removal of a normal phase from a reversed primary component. In these cases a best-fitting great-circle plane was used to estimate the characteristic directions according to the method of McFadden and McElhinny [18] (Fig. 5f).

\subsubsection{Group C}

IRM acquisition and demagnetisation of group $C$ samples show that the magnetisation is here dominated by a high-coercivity mineral (Fig. 4c). IRMacquisition curves clearly differ from the group $A$ and $\mathrm{B}$ curves. The blocking temperatures range from 660 to $680^{\circ} \mathrm{C}$ which is characteristic for hematite. No major changes in susceptibility are observed during heating up to $700^{\circ} \mathrm{C}$. Samples of group $\mathrm{C}$ are found in cycles M16-M43 in Metochia B.

NRM intensities range from 1 to $3 \mathrm{~mA} / \mathrm{m}$, initial susceptibilities from 80 to $160 \times 10^{-6} \mathrm{SI}$. Demagnetisation diagrams show that a large normal component is removed at temperatures of $240^{\circ} \mathrm{C}$. At higher temperatures a low-intensity cluster is observed, always indicating normal magnetisation directions (Fig. 5 h,i). The samples from cycles M40 and M43 in Metochia C, however, give clearly reversed primary directions whereas demagnetisation of the samples from the same cycles in Metochia B results in clusters which are characteristic for group C (Fig. 5i,j). This indicates that the high-coercivity mineral (hematite) is of secondary origin and most likely generated by subrecent weathering of the sediment.

\subsubsection{Group D}

Samples attributed to group D again show a low coercivity mineral as the dominant carrier of the remanence (Fig. 4d). Maximum blocking temperatures of approximately $580^{\circ} \mathrm{C}$ point to the presence of magnetite. The difference with group $\mathrm{A}$ is the response of susceptibility during heating of the sedi-

\footnotetext{
Fig. 3. Polarity zones, lithology, cycle numbers and ranges of planktonic foraminifera, Bolboforma and dinoflagellates of the Gibliscemi section. Biostratigraphic data of planktonic foraminiferal marker species are based on surveying a standard number of fields (27 out of 45 ) on a rectangular picking tray and semi-quantitatively presented in terms of absence, trace ( $<3$ specimens per 9 fields of picking tray), rare (3-10), common (10-30) and frequent ( $>30)$ indicated by increasing bar thickness. For numbered foraminiferal bioevents see caption to Fig. 2. Semi-quantitative distribution of dinoflagellate marker species is based on 200-counts and presented in terms of absence, trace $(1-5 \%)$, rare $(5-10)$, common $(10-25)$ and frequent $(>25)$ indicated by increasing bar thickness. Encircled dinoflagellate events refer to (a) LO of $C$. sp. A, (b) LCO of $M$. sp. A, (c) FO of $I$. maculatum, (d) LO of $P$. golzowenze, (e) FO of C. labradorii, (f) LO of $M$. sp. A, (g) of LO C. labradorii, (h) LCO of T. psilatum, and (i) LO of L. truncatum.
} 


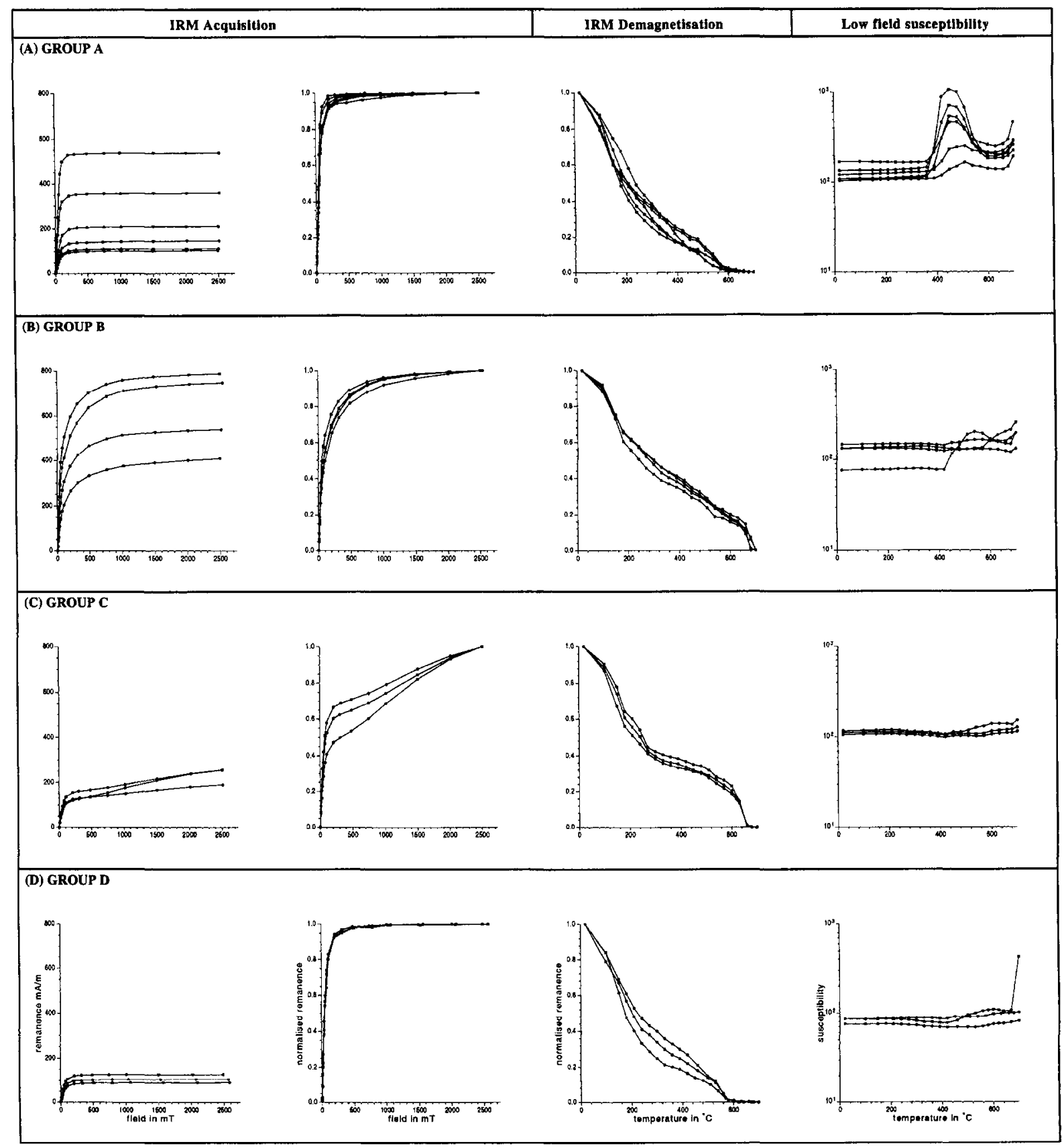

Fig. 4. Examples of rock magnetic tests for selected samples of the four groups (A, B, C and D) of the Metochia section. In the IRM acquisition diagrams, the initial steep rise $(0-300 \mathrm{mT})$ points to magnetite, the gradual increase at high fields suggests the presence of hematite (see especially group $C$ ). Stepwise thermal demagnetisation of the normalised NRM also show the presence of magnetite (A and D) and hematite (B and $\mathrm{C}$ ). Low field susceptibilities display chemical reactions during thermal demagnetisation. Note the sudden increase at approximately $400^{\circ} \mathrm{C}$ in group $\mathrm{A}$. 


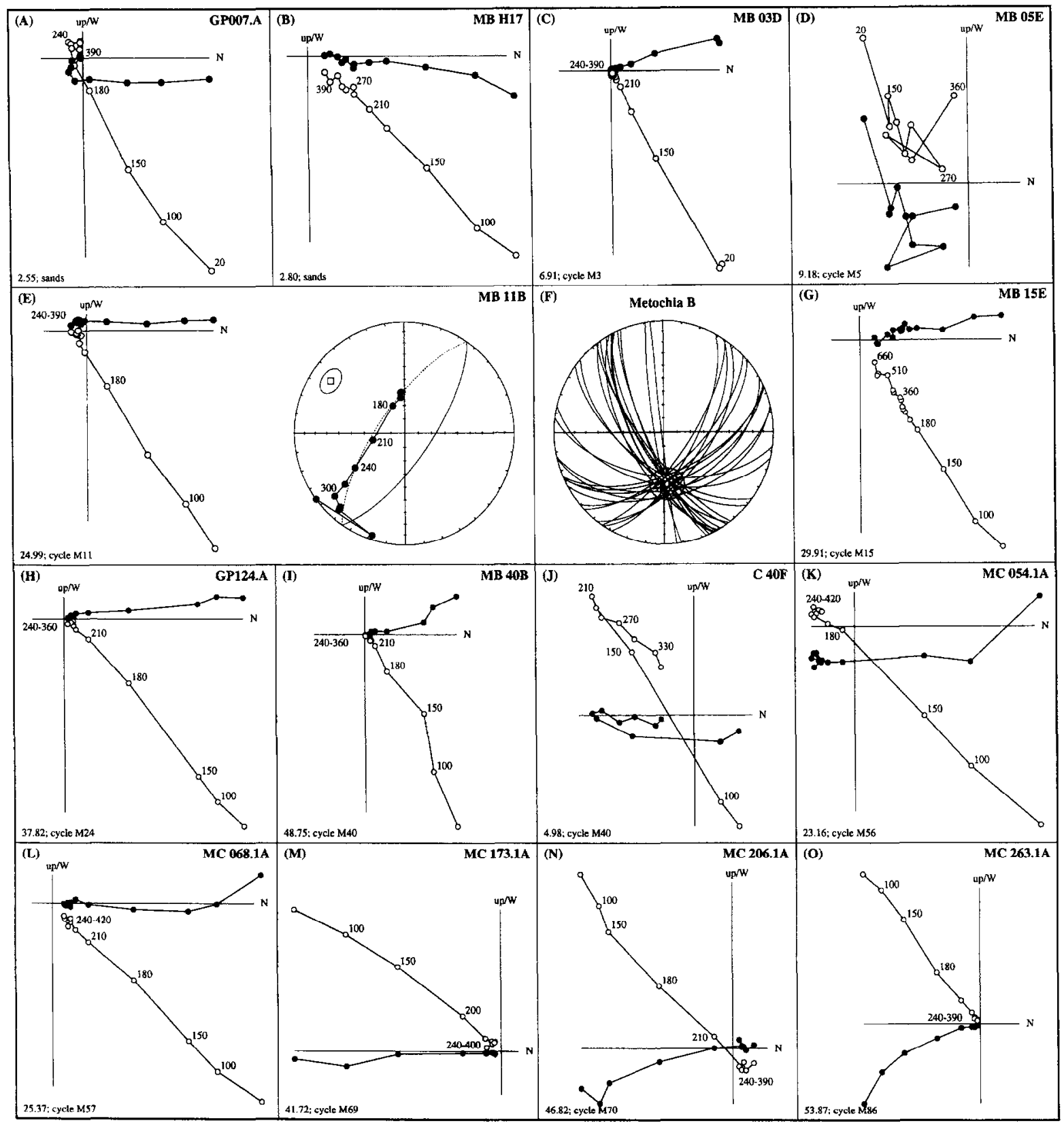

Fig. 5. Thermal demagnetisation diagrams for samples from the Metochia section. Closed (open) symbols represent the projection of the vector end-points on the horizontal (vertical) plane; values represent temperatures in ${ }^{\circ} \mathrm{C}$ : stratigraphic levels are in the lower left-hand corner. (E) Example showing no clear decay to the origin; the great circle in the equal-area projection suggests that a reversed ChRM is not fully resolved. $\square=$ the normal to the plane with its error. (F) The intersections of all great-circle planes as estimate of the primary directions. 
ment. In group D, no increase in low field susceptibilities is observed between temperatures of 390 $500^{\circ} \mathrm{C}$. Samples attributed to group D are found in cycle M57 of Metochia B and in cycles M57-M91 of Metochia C.

NRM intensities range from 0.17 to $2.5 \mathrm{~mA} / \mathrm{m}$, susceptibilities from 35 to $150 \times 10^{-6} \mathrm{SI}$. The lower values of the initial susceptibility are probably related to a higher $\mathrm{CaCO}_{3}$ content. Demagnetisation diagrams show that a secondary low-temperature ( $\mathrm{LT}$ ) component is removed at temperatures of $240^{\circ} \mathrm{C}$ (Fig. $5 \mathrm{k}-\mathrm{o}$ ). In the lower part of the section this I.T component has a normal present-day field direction, whereas in the upper part of the section this $L T$ component has a reversed direction (Fig. 5m-o). After removing the $\mathrm{L} T$ component, a relatively small but well-determined high-temperature ( $\mathrm{H} T$ ) component reveals a consistent pattern of both normal and reversed polarities (Fig. 5). We suggest that the $\mathrm{HT}$ component $\left(>240^{\circ} \mathrm{C}\right)$ represents the primary ChRM component and the LT component a secondary post-depositional overprint. The reversed polarity of the $L T$ component might be generated by late-diagenetic processes, for instance when the sediment became uplifted/exposed during a period of reversed polarity. The rock magnetic results indicate

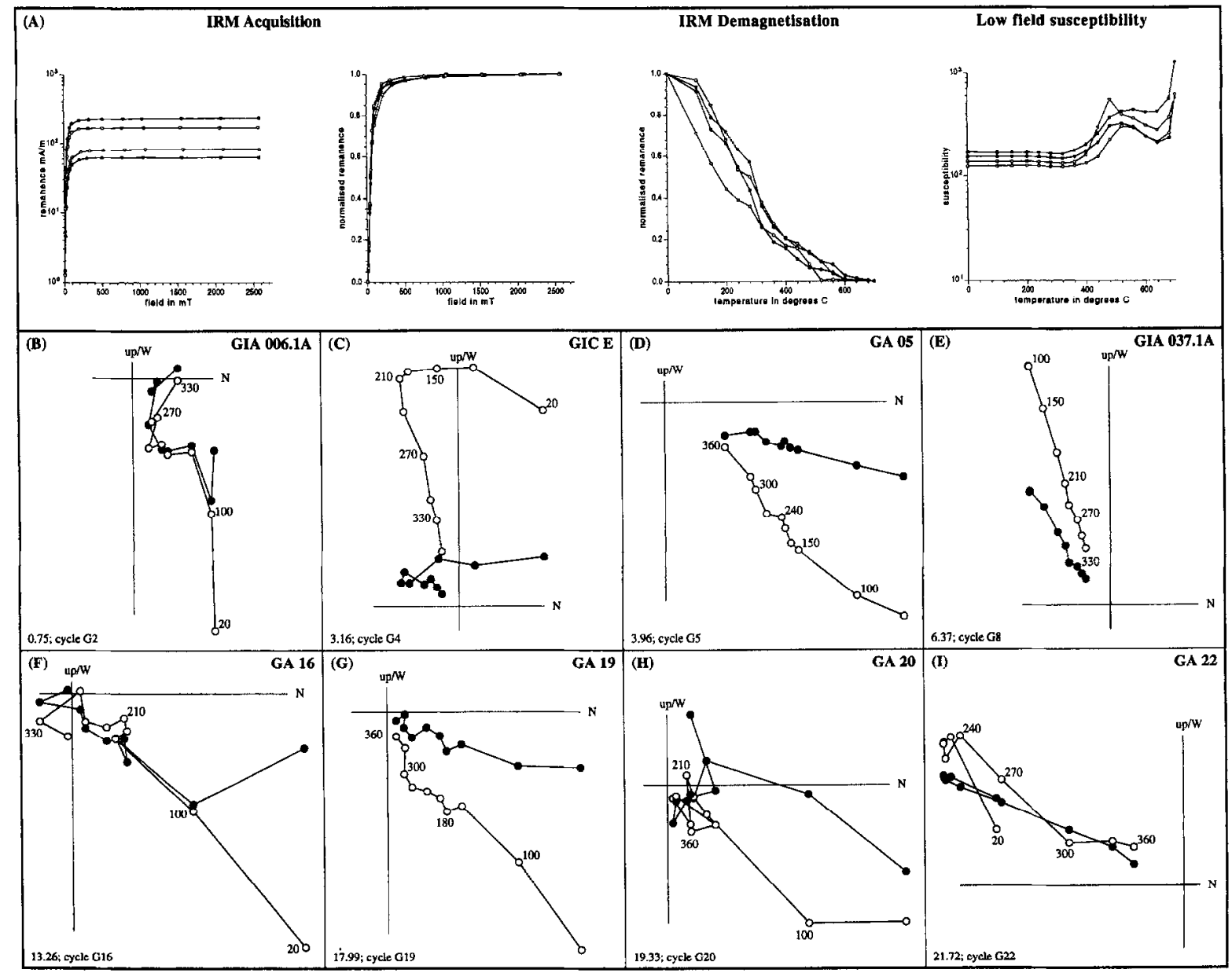

Fig. 6. (A) Examples of IRM acquisition, subsequent IRM demagnetisation and low-field susceptibilities for selected samples of the Gibliscemi section. (B-I) Thermal demagnetisation diagrams. See also captions to Figs. 4 and 5. 
that the secondary component in Metochia $\mathrm{C}$ is a low coercivity (probably magnetite) component.

The ChRM directions and polarity zones of the composite Metochia section show that at least seventeen polarity reversals are recorded (Fig. 2; see also Appendix A). The magnetostratigraphic results from the partly overlapping Metochia $\mathrm{B}$ and $\mathrm{C}$ sections confirm the cyclostratigraphic correlation. No primary components could be determined in the middle part of the Metochia B section (M16-M42). In this part of the section the secondary component totally overprints the primary component and hence no original polarity can be determined. The lower part of Metochia $C$ is less weathered and yields good results for cycles M40-M42. The paleomagnetic signal of cycles M36-M39 is too weak to determine a reliable polarity.

\subsection{Sicily: Gibliscemi section}

The NRM intensities of the Gibliscemi section are very low, $50-150 \mu \mathrm{A} / \mathrm{m}$ and initial susceptibilities range from 100 to $200 \times 10-6$ SI. Only for the lower part of the section reliable magnetostratigraphic data could be derived (Fig. 3). The best demagnetisation diagrams were given by samples of the lowermost part (cycles G1-G25) of the section.

IRM acquisition and subsequent demagnetisation for selected samples of the lower part of Gibliscemi $A$ indicate the presence of a low-coercivity mineral with a maximum unblocking temperature of 560 $600^{\circ} \mathrm{C}$ (Fig. 6a). This suggests that magnetite is the dominant carrier of the magnetism. Heating of the samples results in an increase of the low field susceptibility between temperatures of 400 and $480^{\circ} \mathrm{C}$ after which a decrease to $600^{\circ} \mathrm{C}$ is observed. These results generally show the same characteristics as the samples of Group A of the Metochia section.

Thermal demagnetisation often reveals that a secondary, normally directed component is removed at a temperature of $240^{\circ} \mathrm{C}$ (Fig. 6c) although this component is not always present (Fig. 6e). The ChRM component is subsequently demagnetised at temperatures of approximately $400^{\circ} \mathrm{C}$. Demagnetisation at higher temperatures results in a large and randomly directed viscous component, compatible with an increase in susceptibility probably caused by the oxidation of pyrite to magnetite [17]. Demagnetisation diagrams are often difficult to interpret because of the very weak NRM (Fig. $6 \mathrm{~b}, \mathrm{f}, \mathrm{h}$ ). We interpreted a direction as reliable only if a linear decay to the origin was observed. The reliable ChRM directions show an average clockwise rotation; $20^{\circ}$ for the normal polarities and $25^{\circ}$ for the reversed polarities. Clockwise rotations on Sicily have been found earlier by Scheepers and Langereis [19] who estimated an average clockwise rotation of $34^{\circ}$ for early Pliocene sections from the Caltanissetta basin.

Four polarity reversals are recorded in the lowest part of the section (Fig. 3; see also Appendix A). The results from the Gibliscemi $\mathrm{A}$ and $\mathrm{C}$ sections are in agreement with each other and confirm the positions of the polarity reversals. Unfortunately, the upper two reversals cannot be pinpointed accurately in one sedimentary cycle because of the very weak paleomagnetic signal.

\section{Biostratigraphy}

Planktonic foraminiferal biostratigraphy played an essential role in confirming the cyclostratigraphic correlation between Gibliscemi and Metochia since magnetostratigraphic and dinoflagellate control is poor in one or the other section. Planktonic foraminiferal biostratigraphic correlations are based on the stratigraphic distribution of six species plus the coiling ratio of Neogloboquadrina acostaensis in 337 samples from Gibliscemi and 553 from Metochia (see Figs. 2 and 3). The distribution of these six species is based on surveying a standard number of fields (27 out of 45) on a rectangular picking tray and specified in semi-quantitative terms (frequent, common, rare, trace) for Gibliscemi and in qualitative terms (presence, absence) for Metochia. Most species display an intermittent distribution pattern. This holds in particular for the sinistrally-coiled Globorotalia menardii 4 in the lower part of both sections (G1-G50 and M1-M45). This species occurs more regularly between G51-G80 and M46M68 but then vanished until its brief re-occurrence in G85 of Gibliscemi and in M69 of Metochia. The top of this brief re-occurrence event is equated with the LCO of G. menardii 4 even though this species shows a final and extremely brief influx in the upper part of the range of G. menardii 5 [20]. Fig. 2 shows 
that the sinistral G. menardii 4 is followed in succession by the dextral $G$. menardii 5 and the sinistral Globorotalia conomiozea group. This succession (although differently labeled) has been noticed in many locations in the Mediterranean [21-25], and the absence of $G$. menardii 5 in Gibliscemi, therefore, points to a major hiatus at $108 \mathrm{~m}$ (Fig. 3). The unkeeled globorotaliid group lacks systematic changes that can be used for correlating both sections. An exception is the FO of Globorotalia nicolae - a dextrally-coiled and biconvex form with inflated chambers - which is a useful bioevent for correlating lower Messinian sequences in the Mediterranean region. The FO of $G$. nicolae in Metochia shortly preceeds the first occurrence of diatomites and follows a relatively long interval in which unkeeled globorotaliids are absent. The top of Gibliscemi reaches into this absence interval. Another useful species is Catapsydrax parvulus, which is the last representative of the Catapsydrax group. Catapsydrax parvulus is a senior synomym of Globorotalia falconarae, which, in the Mediterranean ranges up into Zone N16 [26,27]. Catapsydrax parvulus is common to frequent in cycles $\mathrm{G1-}$ G37 of Gibliscemi and in M1-M29 of Metochia and its maximum size is significantly larger than in any younger level (with the exception of a brief reoccurrence in G72 and M61; see Figs. 2 and 3). The LCO of these large-sized $C$. parvulus types is a useful bioevent for the (eastern) Mediterrancan. Catapsydrax parvulus is extremely scarce from the LCO level of the large-sized types up to cycle G37 and M29, but becomes again more frequent from cycles G53 and M47 up to its LO level (M71) in Metochia (Figs. 2 and 3).

Sphaeroidinellopsis seminulina is common to frequent in a discrete interval which ranges from $\mathrm{G} 72$ to G80 and from M61 to M68 (Figs. 2 and 3). The base of this interval coincides with the bricf re-occurrence of large-sized $C$. parvulus types, while the top corresponds with the base of the longer-term absence interval of $G$. menardii 4 preceding its LCO level. Scattered occurrences of $S$. seminulina are found beyond this interval in cycle M10 and M68M69. The last species with biostratigraphic significance is $N$. acostaensis. Coiling of this species is dominantly dextral from $\mathrm{G} 1$ to $\mathrm{G} 10$ and from $\mathrm{M} 1$ to M6, whereafter coiling changes in a series of highamplitude fluctuations up to G19 in Gibliscemi and M15 in Metochia. Above that level dominant sinistral coiling prevails, although at some levels coiling reverts to dominant dextral.

The stratigraphic distribution of the species listed above provides 11 first-order bioevents (summarized in Appendix B), which are perfectly isochronous compared to the cyclostratigraphic framework and which substantially improve the biostratigraphic resolution in this time span. However, many more isochronous surfaces can be drawn between both sections on the basis of second-order bioevents. Examples of such second-order bioevents are several short-term incursions of Globoquadrina altispira, the many short-term absence intervals of $G$. menardii 4 , and the brief reoccurrence of large-sized $C$. parvulus types. One of the most remarkable second-order bioevents is the single short incursion of abundant Globoquadrina dehiscens in cycle G32 of Gibliscemi and in the equivalent cycle M28 of Metochia.

Along with the planktonic foraminiferal analysis we recorded the absence and presence of 5 species of the calcareous microfossil group of Bolboforma (Protophyta, [28]). Figs. 2 and 3 show that the sections Metochia and Gibliscemi have three species in common but their stratigraphic distribution shows little similarity. This is surprising because the opposite is true for the distribution of the planktonic foraminifers. We conclude, therefore, that this group has little biostratigraphic significance in this part of the Mediterranean and for the time slice studied.

Dinoflagellate cysts are abundant in the Gibliscemi section, but rare in Metochia. Actually, $75 \%$ of the samples in Metochia was barren possibly due to intense weathering. 200-counts on 72 samples from below the hiatus in Gibliscemi yielded 7 species with

Fig. 7. Stratigraphic framework showing the magnetostratigraphy, integrated biostratigraphy and cyclostratigraphy of the Kastelli, Faneromeni, Metochia and Gibliscemi sections and the correlation of the magnetostratigraphy to the geomagnetic polarity time scale of Cande and Kent [1]. Cyclostratigraphic correlations arc based on sedimentary cycle patterns. 


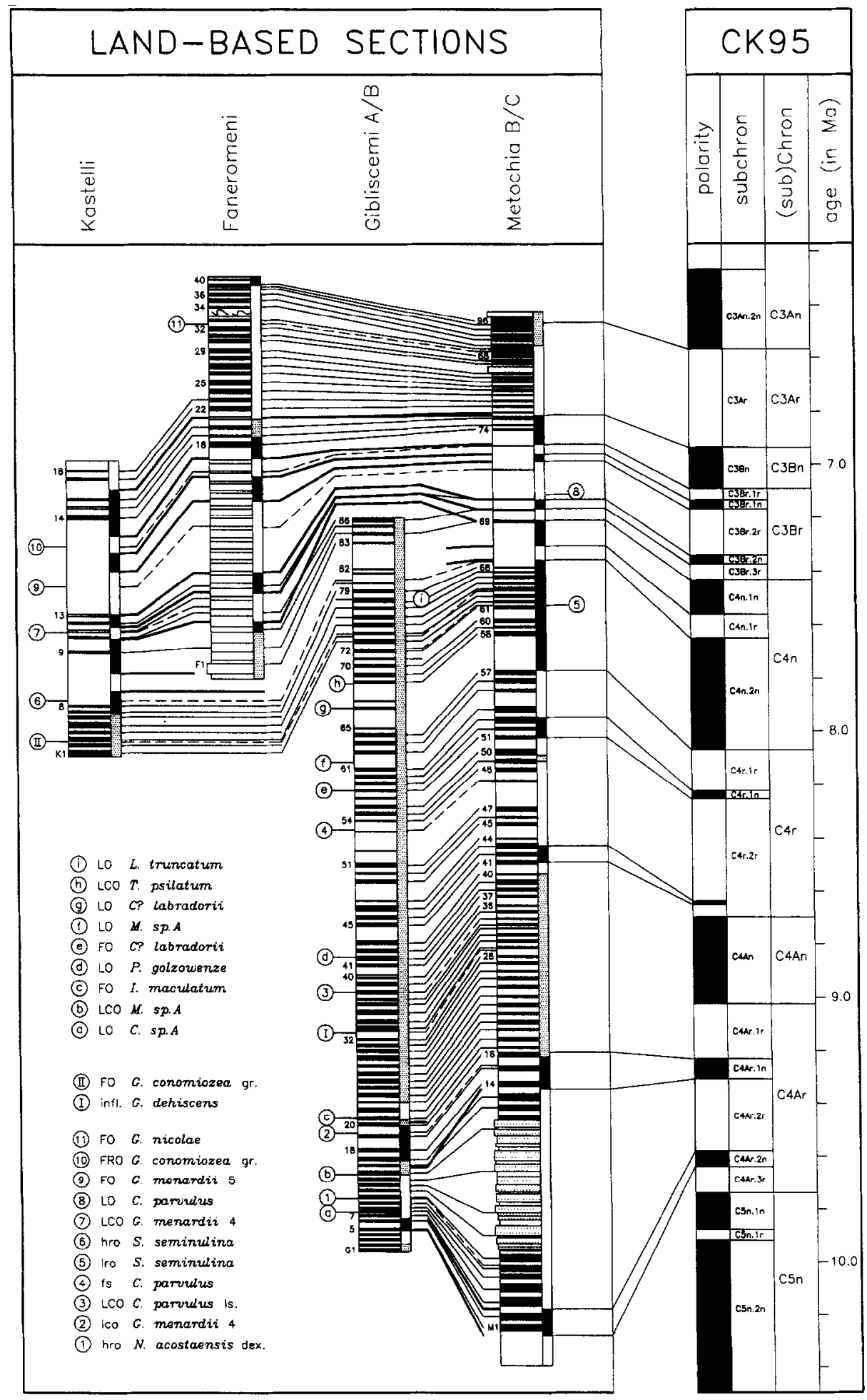


(potential) biostratigraphic significance (Fig. 3). The LO of Cerebrocysta sp. A in cycle G6 has also been recorded by Powell [29] in the lower part of the Tortonian type section along the Rio MazzapiediCastellania and might be a useful bioevent for (at least) the Mediterranean region. The LO of Palaeocystodinium golzowense in G41 seems to have (semi-)global significance since it has been recorded in a number of upper Miocene sequences from outside the Mediterranean as well (e.g. [30-33]). Mendicodinium sp. A has its LO in G61. The highest occurrence of Labyrinthodinium truncatum in G78 represent its true last occurrence since this species is absent in the Faneromeni section, which covers the interval missing in Gibliscemi due to a hiatus. The LO of $L$. truncatum is a useful bioevent since it has been recorded in a number of late Miocene sections from outside the Mediterranean as well [30-33]. Tectatodinium psilatum ranges up into the Faneromeni section but its frequency drop in G68 is a very distinct and probably useful bioevent. Whether the FO of Impagidinium maculatum in G21 and the limited range of Corrudinium labradorii (from G58 to G66) have biostratigraphic significance will become evident after studying additional late Miocene sections from within and outside the Mediterranean.

\section{Integrated stratigraphic framework}

The data presented in this paper provide a highresolution integrated stratigraphic framework for the Mediterranean upper Miocene. Since the Gibliscemi section recorded a large hiatus in its upper part and also did not provide a good magnetostratigraphy, we incorporated the earlier data from the Faneromeni and Kastelli sections of Crete which showed reliable results for the corresponding interval $[10,11]$. In general, the magnetostratigraphic and biostratigraphic data are consistent with, and thus essentially confirm, the cyclostratigraphic correlations, although minor discrepancies exist (Fig. 7). The polarity reversals of the upper part of the Metochia section are consistently found at a slightly lower (cyclo)stratigraphic position than at Faneromeni and Kastelli, as confirmed by the biostratigraphic data. Furthermore, the consistent offset of generally $1 / 2$ to 1 cycle suggest that this discrepancy is probably not caused by a misinterpretation of the paleomagnetic data. Diagenetic processes, related to the paleoredox conditions, may cause a delay of the acquisition of the NRM, which is dependent on the lithology of the sediment [34]. Such a delayed acquisition is a likely explanation for the observed discrepancies between Metochia and Crete.

\section{Correlation to the GPTS}

Since the results of all sections are generally in good agreement, we can use the polarity sequences to construct a chronostratigraphic framework and to assign numerical ages to the biostratigraphic events. Correlation of the established polarity patterns (Appendix A) to the GPTS has been made by reference to the most recent published version CK95 [1]. The results of the Cretan sections were correlated earlier to the older CK92 [35] time scale [11]. In CK95, the polarity patterns are identical to CK92; differences are caused by the incorporation of new and additional calibration points which results in slightly older ages for the polarity reversals. Hence, the correlation of the polarity patterns of the Faneromeni and Kastelli sections to CK95 remains the same but only results in a minor change in age (Fig. 7). This was also suggested by the modified CK92_MOD time scale of Krijgsman et al. [11].

In contrast to the Cretan sections, the Metochia section could be extended further downward which resulted in the recording of eight additional polarity reversals (Fig. 7). Correlation to CK95 shows that the long normal interval (M57-M68) corresponds to chron $\mathrm{C} 4 \mathrm{n} .2 \mathrm{n}$ and the first short normal interval (M51-M53) to chron C4r.1n. The second short normal interval (M41-M42) cannot be correlated to any chron in CK95. It might correspond to the so-called cryptochron C4r.2r-1 which has a duration of $16 \mathrm{kyr}$ according to CK95. This short polarity interval is also found in ODP Leg 138 [36]. The duration of this interval, estimated from thickness and sedimentation rate, ranges from 33 to $58 \mathrm{kyr}$ in Schneider [36], which is in agreement with our results that indicate a duration of 30-40 kyr (1.5-2 sedimentary cycles). Hence, a duration of $16 \mathrm{kyr}$ in CK95, based on ocean floor anomaly patterns, seems too short. Schneider [36] also recorded another cryptochron, which he 
called C4r.1r-1, that is not recorded in the Cande and Kent $[1,35]$ time scale. According to our results, only reversed polarities are recorded in the corresponding time interval. There is one level (M49), however, for which we obtained normal polarities, but rock magnetic experiments suggest that we are dealing here with a normal (hematite; group B) overprint. This level thus reveals the same rock magnetic characteristics as the long remagnetised interval (M16-M39) in Metochia B. This remagnetised interval is marked by the (regular) occurrence of numerous sapropels whereas the remagnetised M49 level occurs in a small group (M48-M50) of sapropels. In this respect, it is suspect that two short normal polarity intervals coincide with small sapropel groups (i.e. M41-M44 and M51-M54). Their rock magnetic characteristics, however, suggest a primary origin of these normal polarities.

No reliable data are derived from the middle part of the Metochia B section (M16-M39) because the primary component is probably totally overprinted by a normally directed secondary weathering component. Also in the Gibliscemi section no polarities could be determined for the time-equivalent interval. The combined results of Gibliscemi and Metochia show that four polarity reversals are recorded at the base of the sections, which determine two short normal polarity intervals. The only likely correlation to CK95 of the $20 \mathrm{kyr}(\mathrm{Ml}$; G5) and $50 \mathrm{kyr}$ (M14M15; G18-G19) normal polarity intervals is to the subchrons C4Ar.1n and C4Ar.2n (Fig. 7). According to this correlation, it appears that we did not record the upper and lower reversal boundaries of chron C4An. Our correlation is furthermore confirmed by the duration of the interval between the reversal boundaries C4r.1n (o) and C4Ar.1n (y), which is 973 kyr in CK95 and $1040 \mathrm{kyr}$ based on the estimated number of $( \pm 50$ precession related) sedimentary cycles.

The established magnetostratigraphic correlation results in accurate ages, according to the CK95 time scale, for the following bioevents (Appendix B); (1) highest regular occurrence (hro) of dexral $N$. acostaensis (chron C4Ar.2r; $9.53 \pm 0.01 \mathrm{Ma}$ ); (2) lowest common occurrence (lco) of $G$. menardii 4 coincident with the last of a series of high-amplitude changes in \% dextral $N$. acostaensis (C4Ar.1n (y); $9.24 \pm 0.01 \mathrm{Ma}$ ); (3) LCO of large sized C. parvulus types $(8.81 \pm 0.01 \mathrm{Ma})$; (4) frequency shift in $C$. parvulus from nearly absent to commonness ( $\mathrm{C} 4 \mathrm{r} .2 \mathrm{r}$; $8.40 \pm 0.02 \mathrm{Ma}$ ); (5) the Iro of S. seminulina, coincident with a brief re-occurrence of large-sized $C$. parvulus types $(\mathrm{C} 4 \mathrm{n} .2 \mathrm{n} ; 7.85 \pm 0.02 \mathrm{Ma}) ;(6)$ the highest regular occurrence (hro) of $S$. seminulina, coincident with the temporary disappearance of $G$. menardii 4 preceding its LCO $(\mathrm{C} 4 \mathrm{n} .2 \mathrm{n}(\mathrm{y}) ; 7.65 \pm$ $0.03 \mathrm{Ma}$ ); (7) the LCO of $G$. menardii form 4 (C3Br.3r; $7.40 \pm 0.02 \mathrm{Ma}$ ); (8) the last occurrence (LO) of C. parvulus (C3Br.2r; 7.32 $\pm 0.01 \mathrm{Ma}$ ); (9) the FO of $G$. menardii form 5 (C3Br.2r; $7.23 \pm 0.01$ $\mathrm{Ma}$; (10) the First Regular Occurrence (FRO) of the G. conomiozea group (C3Br.1r; $7.12 \pm 0.01 \mathrm{Ma})$, (11) the FO of $G$. nicolae (C3Ar; $6.68 \pm 0.01 \mathrm{Ma}$ ). The dinoflagellate bioevents are only determined in the Gibliscemi section which could not be directly dated since this section did not provide a good magnetostratigraphy. Numerical ages for these events are calculated after a cyclostratigraphic correlation of the polarity reversals in the Metochia section to their corresponding position in Gibliscemi (see Appendix B).

\section{The age of the $T / M$ boundary}

The level at $6 \mathrm{~m}$ below the base of the Tripoli Formation in the Falconara section (Sicily) has been proposed in 1979 by Colalongo et al. as the Global Stratotype Section and Point (GSSP) for the Tortonian/Messinian ( $\mathrm{T} / \mathrm{M})$ boundary and serves as such already for 16 years, but the boundary has never been formally defined. The position of the proposed GSSP for the T/M boundary is marked by the FO of G. conomiozea [37].

Globorotalia conomiozea belongs to a late Miocene group of keeled globorotaliids characterized by sinistral coiling and a reniform chamber outline in spiral view [20]. Relatively flat morphotypes are named $G$. dalii and $G$. miotumida (with $G$. dalii being a junior synomym of $G$. miotumida), whereas conical forms are labeled $G$. conoidea, $G$. conomiozea, $G$. saphoa, and $G$. mediterranea depending on the degree of test thickness, axial angularity, and the number of chambers. All these morphotypes, however, completely intergrade, which - in addition to the similarity in chamber outline and 
coiling - is the reason why they all have been lumped into one single category called the $G$. conomiozea group [20] or the $G$. miotumida group [24].

The late Miocene $G$. conomiozea group lived at the mid-to high latitudes of both hemispheres [38] and invaded the Mediterranean near the T/M boundary in response to increased climatic cooling [39,24]. This invasion is preceded, however, by an earlier short-term invasion of thick-shelled and conical representatives of this group at two closely spaced levels slightly above the lowest regular occurrence of $S$. seminulina (Figs. 2 and 3). The G. conomiozea group coexisted with $G$. menardii 4 during the first invasion, but was the sole keeled globorotaliid in the Mediterranean during the second invasion near the $\mathrm{T} / \mathrm{M}$ boundary. The sudden spreading of the $G$. conomiozea group in the Mediterranean during this second invasion ( $=$ FRO of the $G$. conomiozea group) is taken by Langereis et al. [10], Sierro et al. [24], and Krijgsman et al. [11] to mark the T/M boundary. The earliest representatives of the $G$. conomiozea group during this second invasion consist of the flat $G$. miotumida type [23-25]. The conical types arrived later and that is the reason why some authors (e.g. $[23,25])$ place the $\mathrm{T} / \mathrm{M}$ boundary at the first occurrence level of these conical $(=G$. conomiozea) types in accordance with the original proposal of Colalongo et al. [37]. These conical types first occur in section Metochia in cycle M73, shortly after the FRO of the G. conomiozea group, but their regular occurrence starts in cycle M76 in the younger part of chron C3Bn. Hodell et al. [25] might have equated the latter level with the $T / M$ boundary, which would explain why they placed this boundary in chron C3Bn, whereas Langereis et al. [10] and Krijgsman et al. [11] placed the $\mathrm{T} / \mathrm{M}$ boundary midway in chron $\mathrm{C} 3 \mathrm{Br} .1 \mathrm{r}$. The earliest representatives of the $G$. conomiozea group at the proposed $\mathrm{T} / \mathrm{M}$ boundary level in the Falconara section contain already some conical types, but their regular occurrence starts at about $8 \mathrm{~m}$ above the proposed boundary level. This suggests that the proposed $T / M$ boundary level in Falconara is associated with a small hiatus and, therefore, might not be a suitable candidate for defining the $T / M$ boundary. In anticipation of a formal definition we place the $T / M$ boundary at the FRO of the G. conomiozea group (in accordance with [10] and [11]) because this bioevent reflects the most pronounced change in late Miocene globorotaliids and is - irrespective of species concept and labeling procedures - easy to identify within and immediately outside the Mediternanean. The $\mathrm{T} / \mathrm{M}$ boundary defined in this way has an age of $7.12 \mathrm{Ma}$ based on linear interpolation between the younger end of chron $\mathrm{C} 3 \mathrm{Br} .1 \mathrm{n}$ and the older end of chron C3Bn in CK95.

\section{Conclusions}

A high-resolution stratigraphic framework for the late Miocene in the (eastern) Mediterranean is established by combining magnetostratigraphic, biostratigraphic and cyclostratigraphic data from marine sections on Gavdos, Sicily and Crete. Seventeen polarity reversals are recorded which allows an unambiguous correlation to CK95 (Fig. 7). This correlation is used to calculate ages for eleven major planktonic foraminiferal and nine dinoflagellate bioevents (Appendix B). The Tortonian/Messinian boundary, placed at the FRO of the $G$. conomiozea group, is determined in chron $\mathrm{C} 3 \mathrm{Br} .1 \mathrm{r}$ and has an age of 7.12 $\mathrm{Ma}$ according to CK95.

\section{Acknowledgements}

T. van Hoof, G. Postma, P.-J. Verplak, H. Zijderveld, A. Antonarakou, and F, van Welderen Rengers are greatfuly acknowledged for their help in the field. We thank H. de Stigter for using his field data of Gavdos and D. Spiegler (GEOMAR, Kiel) for assisting in determining the Bolboforma species. We also thank the Damorakis family and Georgos Tsigonakis for the good times we had on Gavdos. G. van ' $t$ Veld and G. Ittman prepared the micropaleontological samples. In addition, we thank two anonymous reviewers for their constructive comments. This study was partly supported by The Netherlands Geosciences Foundation (GOA) with financial aid from the Netherlands Organization of Scientific Research (NWO) and the EU-HCM program. This is MIOMAR project contribution No. 3. [RV, MK ] 


\section{Appendix A}

Stratigraphic levels of polarity reversals recorded in the studied sections.

\begin{tabular}{|c|c|c|c|c|c|}
\hline chron & age & $\begin{array}{c}\text { Faneromeni } \\
\text { level in m }\end{array}$ & $\begin{array}{c}\text { Kastelli } \\
\text { level in m }\end{array}$ & $\begin{array}{l}\text { Metochia } \\
\text { level in m }\end{array}$ & $\begin{array}{l}\text { Gibliscemi } \\
\text { level in m }\end{array}$ \\
\hline C3An.2n (o) & 6.567 & $57.43 \cdot 57.50$ & & & \\
\hline $\mathrm{C} 3 \mathrm{Bn}(\mathrm{y})$ & 6.935 & - & $55.72-57.00$ & $92.57 \cdot 93.21$ & \\
\hline $\mathrm{C} 3 \mathrm{Bn}(\mathrm{o})$ & 7.091 & $31.60-32.41$ & $46.83-47.25$ & $90.60-90.74$ & \\
\hline $\mathrm{C} 3 \mathrm{Br} \cdot \ln (\mathrm{y})$ & 7.135 & $28.63-29.73$ & $43.40-43.90$ & $89.69-89.91$ & \\
\hline $\mathrm{C} 3 \mathrm{Br} \cdot \ln (0)$ & 7.170 & $25.84-26.18$ & $40.57-41.03$ & $88.72 \cdot 89.03$ & \\
\hline $\mathrm{C} 3 \mathrm{Br} \cdot 2 \mathrm{n}(\mathrm{y})$ & 7.341 & $15.35-15.60$ & $29.19-29.67$ & $84.91-85.02$ & \\
\hline $\mathrm{C} 3 \mathrm{Br} \cdot 2 \mathrm{n}(\mathrm{o})$ & 7.375 & $11.80-13.40$ & $26.79-27.39$ & $83.89-84.00$ & \\
\hline$C 4 n \cdot \ln (y)$ & 7.432 & $8.35-9.00$ & $24.25-25.40$ & $83.09 \cdot 83.28$ & \\
\hline C4n. In (o) & 7.562 & & $16.75-17.39$ & $80.23-80.87$ & \\
\hline $\mathrm{C} 4 \mathrm{n} \cdot 2 \mathrm{n}(\mathrm{y})$ & 7.650 & & $13.29 \cdot 13.97$ & $78.83-79.87$ & \\
\hline $\mathrm{C} 4 \mathrm{n} .2 \mathrm{n}(\mathrm{o})$ & 8.072 & & & $68.86-69.26$ & \\
\hline C4r. $\ln (y)$ & 8.225 & & & $62.99-63.90$ & \\
\hline C4r.ln (o) & 8.257 & & & $61.36-61.82$ & \\
\hline $\mathrm{C} 4 \mathrm{r} \cdot 2 \mathrm{r}-1(\mathrm{y})$ & 8.635 & & & $50.79-51.60$ & \\
\hline C4r.2r-1 (o) & 8.651 & & & $49.29-49.90$ & \\
\hline C4An $(y)$ & 8.699 & & & & \\
\hline C4An (o) & 9.025 & & & & \\
\hline $\mathrm{C} 4 \mathrm{Ar} \cdot \ln (\mathrm{y})$ & 9.230 & & & & $17.99-20.46$ \\
\hline C4Ar.In (o) & 9.308 & & & $27.35-27.41$ & $12.09-14.25$ \\
\hline $\mathrm{C} 4 \mathrm{Ar} \cdot 2 \mathrm{n}(\mathrm{y})$ & 9.580 & & & $5.83-5.73$ & $4.55-5.05$ \\
\hline C4Ar.2n (o) & 9.642 & & & $2.55-3.10$ & $3.05-3.41$ \\
\hline
\end{tabular}

\section{Appendix B}

Position, age and (sub)chron designation of biostratigraphic events according to CK95. Ages have been obtained by linear interpolation of the sedimentation rate between dated reversal boundarics ( $\sec$ Appendix A). Ages and (sub)ehron designation is given in italies if based on cyclostratigraphic correlations to section with magnetostratigraphy. 


\begin{tabular}{|c|c|c|c|}
\hline 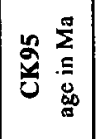 & 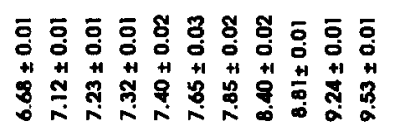 & 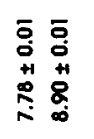 & 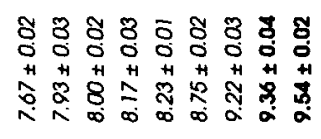 \\
\hline 参 & 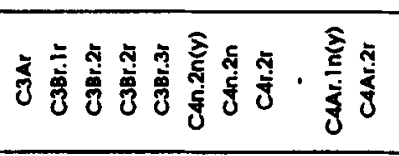 & స్ָ & 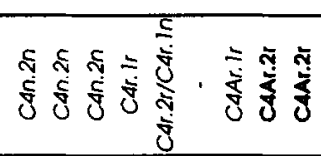 \\
\hline \multirow{2}{*}{ 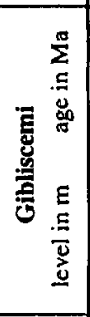 } & 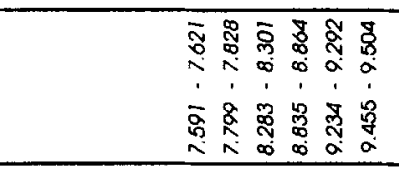 & 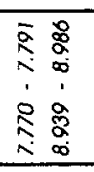 & $\begin{array}{llll} & \\
\\
0\end{array}$ \\
\hline & 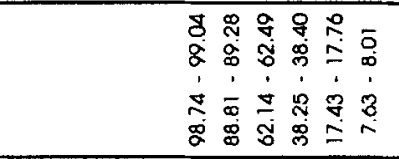 & 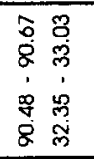 & 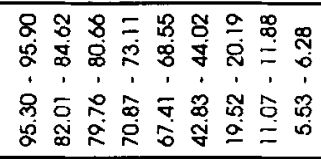 \\
\hline \multirow{2}{*}{ 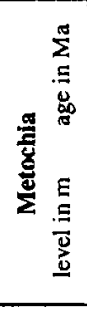 } & 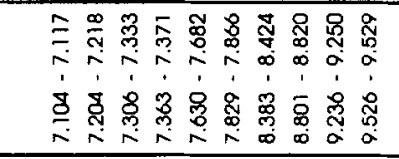 & 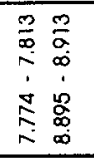 & \\
\hline & 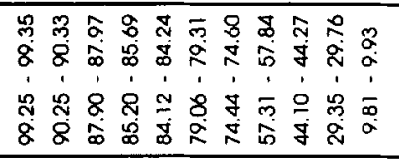 & 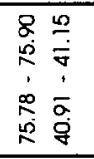 & \\
\hline \multirow{2}{*}{ 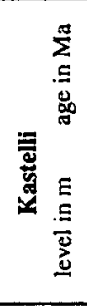 } & 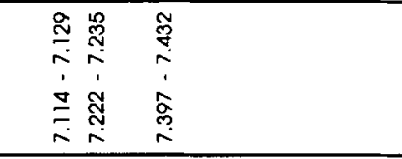 & & \\
\hline & 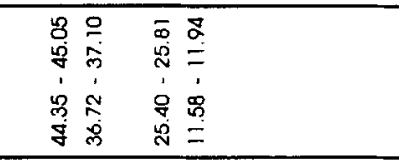 & & \\
\hline \multirow{2}{*}{ 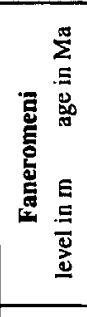 } & 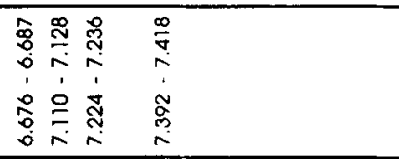 & & \\
\hline & 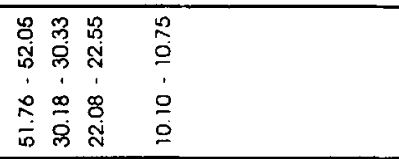 & & \\
\hline $\begin{array}{l}\overrightarrow{\mathrm{t}} \\
\mathrm{z} \\
\mathrm{a}\end{array}$ & 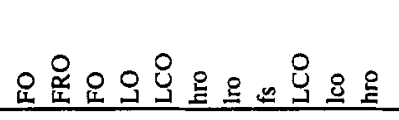 & 온. & 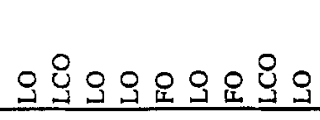 \\
\hline$\frac{d}{\frac{8}{8}}$ & 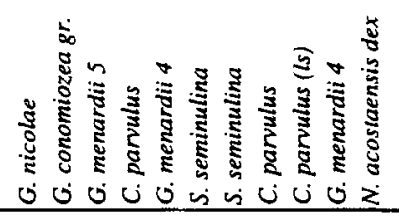 & 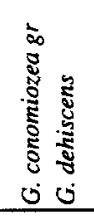 & 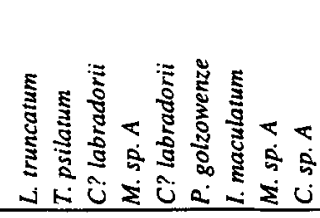 \\
\hline$\stackrel{\circ}{E}$ & $=9 a \infty n \infty n+m N-$ & $=-$ & $\cdots=\infty, 00000$ \\
\hline
\end{tabular}




\section{References}

[1] S.C. Cande and D.V. Kent, Revised calibration of the Geomagnetic Polarity Time Scale for the Late Cretaceous and Cenozoic, J. Geophys. Res. 100, 6093-6095, 1995.

[2] F.J. Hilgen and C.G. Langereis, The age of the MiocenePliocene boundary in the Capo Rosello area (Sicily), Earth Planet. Sci. Lett. 91, 214-222, 1988.

[3] J.E.T. Channell, D. Rio and R.C. Thunell, Miocene/Pliocene boundary magnetostratigraphy at Capo Spartivento, Calabria, Italy, Geology 16, 1096-1099, 1988.

[4] J.E.T. Channell, M. Torii and T. Hawthorne, Magnetostratigraphy of sediments recovered at Sites $650,651,652$, and 654 (Ieg 107, Thyrrhenian Sea), Proc. ODP Sci. Results 107. $335-346,1990$.

[5] J.D.A. Zijderveld, F.J. Hilgen, C.G. Langereis, P.J.J.M. Verhallen and W.J. Zachariasse, Integrated magnetostratigraphy and biostratigraphy of the upper Pliocene-lower Pleistocene from the Monte Singa and Crotone areas in Calabria, Italy, Earth Planet. Sci. Lett. 107, 697-714, 1991.

[6] C.G. Langereis and F.J. Hilgen, The Rossello composite: A Mediterranean and global reference section for the Early to early Late Pliocene, Earth Planet. Sci. Lett. 104, 211-225, 1991.

[7] F.J. Hilgen, Astronomical calibration of Gauss to Matayama sapropels in the Mediterranean and implication for the Geomagnetic Polarity Time Scale, Earth Planet. Sci. Lett. 104. 226-244, $1991 \mathrm{a}$.

[8] F.J. Hilgen, Extension of the astronomically calibrated (polarity) time scale to the Miocene/Pliocene boundary, Earth Planet. Sci. Lett. 107, 349-368, 1991 b.

[9] C.G. Langereis, Late Miocene magnetostratigraphy in the Mediterranean, 180 pp, Ph.D. Thesis, Univ. Utrecht, Geol. Ultraiectina 34, 1984.

[10] C.G. Langereis, W.J. Zachariasse and J.D.A. Zijderveld, Late Miocene magnetobiostratigraphy of Crete, Mar. Micropaleontol. 8, 261-281, 1984.

[11] W. Krijgsman, F.J. Hilgen, C.G. Langereis and W.J. Zachariasse, The age of the Tortonian/Messinian boundary, Earth Planet. Sci. Lett. 121, 533-547, 1994.

[12] A. Negri and L. Vigliotti, Calcareous nannofossil biostratigraphy and paleomagnetism of the Monte Tondo and Monte del Casino sections (Romagna Appennine, Italy), in: Miocene Integrated Stratigraphic Sequence, A. Montanari, G.S. Odin and R. Coccioni, eds., Elsevier, Amsterdam, in press.

[13] C.G. Langereis and M.J. Dekkers, Paleomagnetism and rock magnetism of the Tortonian-Messinian boundary stratotype at Falconara, Sicily, Phys. Earth Planet. Inter. 71, 100-111, 1992.

[14] F.J. Hilgen, W. Krijgsman, C.G. Langereis, L.J. Lourens, A. Santarelli and W.J. Zachariasse, An astronomical (polarity) time scale for the late Miocene, Earth Planet Sci. Lett., this issue, 1995.

[15] $H$. de Stigter. Neogene-Recent compressional tectonics in the southern Hellenic Arc, 34 pp., Intern. Rep. Utrecht Univ., 1989.

[16] G. Postma, F.J. Hilgen and W.J. Zachariasse, Precession- punctuated growth of a late Miocene submarine-fan lobe on Gavdos (Greece), Terra Nova 5, 438-444, 1993.

[17] A.J. Van Velzen, Thermal alteration of magnetic sulphides in marine marls from the Vrica section and the influence on the demagnetization of the natural remanent magnetization, Geol. Ultraiectina 122, 109-145, 1993.

[18] P.L. McFadden and M.W. McElhinny, The combined analysis of remagnetisation circles and direct observations in paleomagnetism, Earth Planet. Sci. Lett. 87, 161-172, 1988.

[19] P.J.J. Scheepers and C.G. Langereis, Analysis of NRM directions from the Rosello composite: implications for tectonic rotations of the Caltanissetta basin (Sicily), Earth Planet. Sci. Lett. 119, 243-258, 1993.

[20] W.J. Zachariasse, The origin of Globorotalia conomiozean in the Mediterranean and the value of its entry level in biostratigraphic correlations, Ann. Geol. Pays. Hellen. 3, 1281-1292, 1979.

[21] W.J. Zachariasse, Planktonic foraminiferal biostratigraphy of the Late Neogene of Crete (Greece), Utrecht Micropaleontol. Bull. 11, 1975.

[22] F.J. Sierro. The replacement of the "Globorotalia menardii" group by the "Globorotalia miotumida" group: An aid to recognizing the Tortonian/Messinian boundary in the Meditarrenean and adjacent Atlantic, Mar. Micropaleontol. 9. $525-535,1985$.

[23] G. Glacon, C. Vergnaud Grazzini, S. Jaccarino, J.-P. Rehault, A. Randrianasolo, J.F. Sierro, P. Weaver, J.E.T. Channell, M. Torii and T. Hawthorne, Planktonic foraminiferal events and stable isotope records in the upper Miocene, Site 654, Proc. ODP Sci. Results 107, 415-428, 1990.

[24] F.J. Sierro, J.A. Flores, J. Civis, J.A. González Delgado and G. Francés, Late Miocene globorotaliid event-stratigraphy and biogeography in the NE-Atlantic and Mediterranean, Mar. Micropaleontol. 21, 143-168, 1993.

[25] D.A. Hodell, R.H. Benson, D.V. Kent, A. Boersma and K. Rakic-El Bied, Magnetostratigraphic, biostratigraphic, and stable isotope stratigraphy of an Upper Miocene drill core from the Sale Briqueterie (northwest Morocco): A high-resolution chronology for the Messinian stage, Paleoceanography 9, 835-855, 1994

[26] S. Iaccarino, Mediterranean Miocene and Pliocene planktic foraminifera, in: Plankton Stratigraphy, H.M. Bolli, J.B Saunders and K. Perch-Nielsen, eds., pp. 283-314, Cambridge Univ. Press, Cambridge, 1985.

[27] M. Chamley, J.E. Meulenkamp, W.J. Zachariasse and G.J. van der Zwaan, Middle to late Miocene marine ecostratigraphy: clay minerals, planktonic foraminifera and stable isotopes from Sicily, Oceanol. Acta 9, 227-238, 1986.

[28] D. Spiegler and F. Rögl, Bolboforma (Protophyta, incertae sedis) im Oligozän und Miozän de Mediterran und der Zentralen Paratethys, Ann. Naturhist. Mus. Wien 94, 59-95, 1992.

[29] A.J. Powell, The stratigraphic distribution of Late Miocene dinoflagellate cysts from the Castellanian superstage stratotype, northwest Italy, Am. Assoc. Stratigr. Palynol. Contrib. Ser. 17, 129-150, 1986.

[30] L.E. Edwards, Miocene dinocysts from Deep Sea Drilling 
Project Ieg 81, Rockall Plateau, eastern North Atlantic Ocean, Init. Rep. DSDP 81, 581-594, 1984.

[31] M.J. Head, G. Norris and P.J. Mudie, Palynology and dinocysts stratigraphy of the Upper Miocene and lowermost Pliocene, ODP Leg 105, Site 646, Labrador Sea, Proc. ODP Sci. Results 105, 423-451, 1989a.

[32] M.J. Head, G. Norris and P.J. Mudie, New species of dinocysts and a new species of acritarch from the Upper Miocene and lowermost Pliocene, ODP Leg 105, Site 646, Labrador Sea, Proc. ODP Sci. Results 105, 453-466, 1989 b.

[33] M.J. Head, G. Norris and P.J. Mudie, Palynology and dinocysts stratigraphy of the Miocene in ODP Leg 105, Hole 645E, Baffin Bay, Proc. ODP, Sci. Results 105, 467-514, $1989 \mathrm{c}$.

[34] A.A.M. Van Hoof, B.J. van Os, J.G. Rademakers, C.G. Langereis and G.J. de Lange, A paleomagnetic and geochemical record of the upper Cochiti reversal and two subsequent precessional cycles from southern Sicily (Italy), Earth Planet. Sci. Lett. 117, 235-250, 1993.

[35] S.C. Cande and D.V. Kent, A New Geomagnetic Polarity
Time Scale for the Late Cretaceous and Cenozoic, J. Geophys. Res. 97, 13,917-13,951, 1992.

[36] D.A. Schneider, Paleomagnetism of some leg 138 sediments: detailing Miocene magnetostratigraphy. Proc. ODP, Sci. Results 138 , in press.

[37] M.L. Colalongo, A. di Grande, S. d'Onofrio, L. Gianelli, S. Iaccarino, R. Mazzei, M.F. Poppi Brigatti, M. Romeo, A. Rossi and G. Salvatorini, A proposal for the Tortonian-Messinian boundary, Ann. Géol. Pays Hellén. 1, 285-294, 1979.

[38] W.A. Berggren, Neogene planktonic foraminiferal biostratigraphy and biogeography: Atlantic, Mediterranean and Indopacific regions, in: Pacific Neogene Datum Planes (Contributions to Biostratigraphy and Chronology), N. Ikebe and R. Tsuchi, eds., pp. 111-161, Univ. Tokyo Press, Tokyo, 1984.

[39] W.J. Zachariasse and P. Spaak, Middle Miocene to Pliocene paleoenvironmental reconstruction of the Mediterranean and adjacent Atlantic Ocean: planktonic foraminiferal record of southern Italy, in: Reconstruction of Marine Paleoenvironments, J.E. Meulenkamp, ed., Utrecht Micropaleontol. Bull. $30,91-110,1983$. 